\title{
The Rule Against Disturbing Plain Meaning of Writings
}

\author{
James P. McBaine*
}

IN A discussion of any phase of the so-called parol evidence rule, it seems worth while, probably necessary, to keep in mind that actually there is no single rule which properly may be called The Parol Evidence Rule. There are four parol evidence rules, not one. ${ }^{1}$ One parol evidence rule has to do with integration. This rule deals with the problem whether a party or parties have embodied in a written instrument or instruments his or their legal acts. ${ }^{2}$ A second parol evidence rule relates to interpretation of written instruments, the application of written instruments to external objects. ${ }^{3}$ A third rule has to do with the creation of legal acts and hence is concerned with whether they are what they purport to be, whether they are void or voidable. ${ }^{4}$ The fourth rule relates to the solemnization of legal acts and therefore deals with the question whether the formalities of the law have been complied with; for example, the sufficiency of a mem-

*Professor of Law, University of California.

1 WIGMIORE, EVIDENCE (3d ed. 1940) \$2400.

2 United Iron Works v. Outer Farbor Dock, etc., Co. (1914) $168 \mathrm{Cal} .81,141$ Pac. 917, (1914) 3 CALIF. L. REv. 86 (holding oral evidence not admissible to prove a warranty, not embodied in a written contract of a sale of a dredge); Estate of Gaines (1940) $15 \mathrm{Cal}$. (2d) 255, 100 P. (2d) 1055 (holding oral evidence not admissible to prove that a written instrument respecting securities in a safe deposit box was only an arrangement for settling the estate of one of the parties upon his death); Mitchell v. Lath (1928) 247 N. Y. 377; 9 WIGMrORE, op. cit. supra note 1, \$\$2401, 2425.

3 Reed v. Insurance Co. (1877) 95 U. S. 23; Balfour v. Fresno C. \& I. Co. (1895) 109 Cal. 221, 41 Pac. 876 (holding parol evidence admissible to prove that the words in a contract "the first payment to be made the first Monday in September after the water has been brought upon the said land", meant payments should not commence until the water was used); 9 WIGMORE, op. cit. supra note $1, \S \S 2401,2458$.

4 P. A. Smith Co. v. Muller (1927) 201 Cal. 219, 256 Pac. 411 (holding oral evidence admissible to prove that a written contract to purchase glass was a "sham" made only to enable one of the parties to obtain a supply of merchandise from the manufacturer); Harper v. French (1938) 29 Cal. App. (2d) 214, 84 P. (2d) 216 (holding parol evidence admissible to prove that a promissory note given in payment of a broker's counmission was not to become effective until the happeming of a condition precedent, viz., payment of the second installment due under an agreement to purchase land); Walter Pratt \& Co.v. G. W. Chaffin \& Co. (1904) 136 N. C. 350, 48 S. E. 768; 9 WrGMrore, op. cit. supra note 1, $\S \$ 2401,2404$. 
orandum within the statute of frauds. ${ }^{5}$ The problem to be discussed, briefly, is a problem of interpretation not one of integration, solemnization or creation of legal acts.

When litigants introduce in evidence written instruments, they must be imterpreted by the court. There is no way by which this burden can be avoided by the courts simce it is humanly impossible for man to prepare his written instruments, deeds, contracts, wills, and so forth, and have their terms and provisions fulfilled by magic. No magic exists which men can call to their aid and thereby have the terms of their written instruments carried out to their complete satisfaction. Magic works only for writers of fiction-not for ordinary mortals in the transaction of the ordinary affairs of life. People write a variety of instruments of legal import and human beings must carry them out if they are to be anything more than writing exercises, or mere narrations of things past or prophecies of things to come. Written instruments, if they are to accomplish anything in the realm of law, must be applied by inan to external objects. ${ }^{6}$ Whether writings of legal significance have been or are about to be properly applied, presents a problem of interpretation for the courts, if men disagree, which they frequently do, and take their disputes to the courts for settlement. The discussion that follows relates to one, only, of many questions raised in connection with the interpretation rule, namely, whether the conventional rule which forbids the introduction of parol evidence where.the writing is plain on its face, is a sound one-with soine emphasis in the discussion on the law of Califorma. It is believed that the rule against disturbing plain meaming is unsoundopposed to reality-and surely, by virtue of specific legislation, has no place in the law of California.

The problem of interpretation in all legal systems has always been and is now a troublesome one. Certainly this is true of AngloAmerican law, and it is apparent even upon a cursory examination of our law books fròm the Year Books down to the advance sheets of the decisions of any American court. No faith is to be placed, in the idea that a facile phrase or "complete pocket precept" can be hit upon which will be easily understood and unerringly applied to any

5 Empire Investment Co. v. Mort (1915) 169 Cal. 732, 147 Pac. 960 (holding parol evidence not admissihle to prove an oral agreement respecting an easement); Imperator Realty Co. v. Tull (1920) 228 N. Y. 447, 127 N. E. 263 ; Friedman \& Co. v. Newman (1931) 255 N. Y. 340, 174 N. E. 703; 9 WIGMORE, op. cit. sutpra note 1, §\$2401, 2454.

6 Ibid. $\$ 2458$. 
and all circumstances and with correct results. Problems of interpretation must be solved the hard way. A maxim or a neatly phrased rule covering all situations is quite likely to be a snare and a delusion.

Various attempts have been made to lay down a rule for the interpretations of writings. One was a rule attributed to Sir Francis Bacon. In this rule, which was widely used in the United States, a distinction is made between latent and patent ambiguities. Bacon's distinction between latent and patent ambiguities?-Maxim 25-as misunderstood for a general rule of interpretation nearly two centuries after he wrote it, was that oral evidence is admissible to aid in the interpretation of a writing if there is a latent ambiguity, but where there is a patent ambiguity it can only be cured by the writing itself. This concept of interpretation, which has been thoroughly discredited, ${ }^{8}$ may not be so fallacious as the idea that parol evidence is admissible if the writing is ambiguous on its face, but not admissible where the writing is plain on its face, yet the difference in the aunount of error einbodied in the two rules is not very great.

Language is not a perfect code of signals and this fundamental fact must be recognized and acted upon if this important part of the problem of interpretation is to be solved correctly. Thayer wisely said more than forty years ago that no judge ". . . has the right to

7 I4 Bacon's Works (Spedding's Ed. 1861) 273; Thayer's Preitminara Treatise on Evmence (1896) 422, 471. Professor Thayer states Lord Bacon's maxim 25, originally stated as a rule of pleading, first appeared as a rule of evidence, in an anonymous book "The Theory of Evidence", apparently written by Bathhurst in 1761. This book later became a part of Buller's "Nisi Prius". Bacon's misinterpreted maxim still survives, 32 C. J.S. \$961; 20 AMr. JUR. §§1155-1158; 2 JONES ON EVDENCE (4th ed. 1938) $\$ 472$. The writer in 32 C. J. S. $\$ 961$ says that the misinterpreted maxim "has been very generally accepted by the courts as correct." The writer in 20 AMr. JUR. \$1155 says of the distinction between patent and latent ambiguities that it "is gradually disappearing". Let us hope that the time may soon come when it will be of interest only to students engaged in tracing the history of law through periods of formalism to a period of realism.

8 THAYER, op. cit. silpra note 7, at 471. See also GreENLEAF on EvideNCE (16th ed. 1883) $\$ \$ 297-300$, where he discusses Lord Bacon's misinterpreted maxim and concludes that a judge may only pronounce an instrument ambiguous after he had "all the light afforded by the collateral facts and circumstances, which, as we have shown, may be proved by parol." He states that the patent ambiguity of which Lord Bacon spoke is uncertainty which reinains after exhausting all aid from the surrounding circunstances. See Jenny Lind Co. v. Bouer (1858) $11 \mathrm{Cal}$. 194, an opinion by Field, J., where he discusses Lord Bacon's alleged maxim and concluded that the facts present neither a patent nor a latent ambiguity, but an "intermediate class". Other courts have been of the same mind. See 20 Axr. Jor. $\$ 1158$, and cases cited. As late as 1917 the court in Payne v. Commercial Nat. Bank (1917) 177 Cal. 68, 169 Pac. 1007, said, wholly unnecessarily it seems, that parol evidence was not admissible to explain a latent ambiguity. 
expect more of written language than it is capable of, or more care in the use of it than fallible creatures, subject to time and accident, can reasonably supply." J Justice Holmes, while a member of the Supreme Judicial Court of Massachusetts, said, "In every case the words used must be translated in things and facts by parol evidence." 10 Wigmore, the distinguished American authority on Evidence, has taken the same position. He insists that all words require interpretation although the process is often unnoticed; that all words in legal documents must be applied to external objects and that the dogma that plain meaming cannot be disturbed is based upon ancient formalism and the fallacy "... that there is or ever can be some real or absolute meaning." 11 The distinction between words which are plain on the face of a writing and words which are ambiguous on the face of a writing, is based upon the groundless supposition that there is an absolute meaning of words and that people ordinarily correctly use these perfect words.

Two questions arise and must be answered in dealing with the interpretation rule. They are inherent in the problem and cannot be avoided by the use of a facile formula, ${ }^{12}$ for example, the formula that parol evidence is not admissible to disturb plain meaning. One question which must be answered is what standard of interpretation shall be applied by the court. Another is what sources may be examined by the court for a determination of the standard to be adopted. ${ }^{13}$ There are four choices of standards which may be applied in interpreting a writing. One is the ordinary or dictionary meaning of words; a second, the meaning of words in a trade or local group of some sort;

9 THAYER, op. cit. supra note 7 , at 412 .

10 Doherty v. Hill (1887) 144 Mass. 465, 467, 11 N. E. 581, 583. See also Holmes, The Theory of Legal Interpretation (1899) 12 HARv. L. REv. 417, a learned article written by him while he was Chief Justice of the Supreme Judicial Court of Massachusetts.

119 WIGMORE, op. cit. supra note 1, §\$2458, 2462.

12 Writing of Bacon's misinterpreted maxim, Thayer, who took nothing for granted, said, "It seemed to offer valuable help towards settling the troublesome question as to how far you could go in looking at outside facts to aid in construing a written text. To say that a difficulty which was revealed by extrinsic facts could be cured by looking further into such facts, had a reasonable sound; and when it was coupled with a rule that you could not in any way remedy a difficulty which presented itself on the face of the paper, there seemed to be a complete pocket precept covering the whole suhject. When this was found clothed in Latin, and fathered upon Lord Bacon, it might well seem to such as did not think carefully that here was something to be depended upon. The maxim caught the fancy of the profession, and figured as the chief commonplace of the subjcct for many years." THAXER, op. cit. supra note 7, at 472 .

139 WIGMORE, op. cit. supra note $1, \S 2458$. 
a third, the mutual standards of the parties to the writing; and the fourth, the standard of an individual. ${ }^{14}$ Obviously no one standard is to be adopted for all writings under all circumstances. When a court interprets a writing the object is the determination of the meaning of the words in the document. The object being to determine meaning, a choice of the standards to be selected obviously cannot be made by merely reading the written instrument. The surrounding circumstances certainly must be known before a choice can be made. All courts agree to this proposition, if they conclude that the ordinary or dictionary meaning of the written words may not be the proper standard to adopt in the search for meaning. ${ }^{15}$ Many courts also admit parol evidence of the negotiations of the parties, where there are several parties to the writing, when it is determined that the meaning of the writing may not be ascertained by adopting the ordinary or dictionary meaning of the written words before them..$^{16}$ Acceptance of this approach to the problem of interpretation means that all standards of interpretation are only provisional. We cannot find what the writing of the party or parties means unless we look beyond the writing and ascertain what standard is the proper one to be adopted and applied. Preference will and should be given the popular standard. The ordinary or dictionary meaning of words will be accepted unless the court is convinced that another standard was employed in the preparation of the written instrument. ${ }^{17}$

14 Ibid. $\$ 2460$.

15 Bradley v. Steam Packet Co. (1839) 38 U.S. (13 Pet.) 89; Reed v. Insurance Co. (1877) 95 U. S. 23 ; Balfour v. Fresno C. \& I. Co., supra note 3 (where the contract was said to be ambiguous); Smith v. Carlston (1928) 205 Cal. 541, 271 Pac. 1091 (where the contract was thought not to be plain on its face) ; Trustees of Southampton, etc. v. Jessup (1903) 173 N. Y. 84, 65 N. E. 949 ; Firestone Tire \& Rubber Co. v. Werner (1931) 204 Wis. 306, 236 N. W. 118; 9 WIGMORE, op. cit. supra note 1, \$2470, and cases cited; 3 WIIIIsToN on CoNTracTs (Rev. ed. 1936) $\$ 629$, and cases cited. For numerous cases from nearly all American jurisdictions see 20 AMr. JUR. $\$ 1159 ; 32$ C. J. S. $\$ 960$.

169 WIGMORE, op. cit. supra note $1, \$ 2465$, and cases cited; 3 WIILISTON, op. cit. stcpra note $15, \$ 630$, and cases cited. See the following cases where parol evidence of the negotiations was held to be admissible: Balfour v. Fresno C. \& I. Co., supra note 3; Universal Sales Corp. v. California etc. Mfg. Co. (1942) 20 Cal. (2d) 751, 128 P. (2d) 665; Smith v. Vose \& Sons Piano Co. (1907) 194 Mass. 193, 80 N. E. 527; Streppone v. Lennon (1894) 143 N. Y. 626, 37 N. E. 638; Miller v. Wiggins (1910) 227 Pa. 564, 76 Atl. 711 (a trade usage case) ; Firestone Tire \& Rubber Co. v. Werner, supra note 15. Contra (holding parol evidence of negotiations not admissible): Armstrong Pamt Works v. Can Co. (1922) 301 nl. 102, 133 N. E. 711. For additional cases see 32 C. J. S. $\$ 960$.

17 Eustis Mining Co. v. Beer, Sondheimer \& Co. (D. N. Y. 1917) 239 Fed. 976; Kohl v. Frederick (1902) 115 Iowa 517, 88 N. W. 1055; First National Bank of Green- 
Perhaps a few specific instances, always inportant, if not essential, to test generalizations, will serve to bring out the merits and demerits of the several rules respecting interpretation. Reed $v$. Insurance $C{ }^{18}{ }^{18}$ was an action on a policy of marine insurance, on the Minnehaha froin Honolulu via Baker's Island to a port of discharge in the United States. When the ship was lost and suit was brought on the policy the defense was that the risk was suspended at the time of the loss. The policy provided "the risk to be suspended while vessel is at Baker's Island loading". Parol evidence was admitted which showed that Baker's Island is a small, rocky island in mid-ocean, nearly under the Equator, having no harbor or anchorage, and only frequented by man to procure guano. The evidence showed that when ships arrive there to take a cargo of guano, they are moored in the open sea in a perilous position. They are fastened to a coral reef by a system of buoys and heavy chains. In order to load a ship, it is necessary to carry the cargo in small boats to the anchored ship. The place is subject to heavy gales and ships frequently are compelled to put to sea while being loaded in order to avoid destruction. The Minnehaha, sailing from Honolulu on November 7, 1867, arrived near Baker's Island the afternoon of November 20,1867. She came safely to her mooring near the island. Shortly thereafter a heavy gale arose which continued until December 3, 1867, when the ship parted her moorings and was lost. The Supreme Court of the United States, affirming the rulings of the lower federal courts, held that the plaintiff could not recover, that parol evidence was admissible to show the meaning of the words, "the risk to be suspended while vessel is at Baker's Island loading", and, in the light of the facts, that the words ineant that the risk was suspended while the vessel was at Baker's Island for the purpose of loading, and not, as contended by the plaintiff, while it was actually being loaded. Delivering the opinion of the court, Justice Bradley said,

field v. Coffin (1894) 162 Mass. 180, 38 N. E. 444; 9 Wrgmore, op. cit. supra note 1, $\$ 2460$.

In California the rule is clearly stated in the Code of Civil Procedure. Section 1861 of the Code reads as follows:

"Terms to be construed in their general acceptation. The terms of a writing are presumed to have heen used in their primary and general acceptation, hut evidence is nevertheless admissible that they bave a local, technical, or otherwise peculiar signification, and were so used and understood in the particular instance, in which case the agreement inust be construed accordingly."

See also Shean v. Weeks (1917) $176 \mathrm{Cal} .592,169$ Pac. 231.

18 (1877) 95 U.S. 23. 
". . A strictly literal construction would favor the latter meaning.
But a rigid adherence to the letter often leads to erroneous results,
and misinterprets the meaning of the parties. That such was not the
sense in which the parties in this case used the words in question is
manifest, we think, from all the circumstances of the case. Although
a written agreement cannot be varied (by addition or subtraction)
by proof of the circumstances out of which it grew and which sur-
rounded its adoption, yet such circumstances are constantly resorted
to for the purpose of ascertaining the subject matter and the stand-
point of the parties in relation thereto. Without some knowledge
derived from such evidence, it would be impossible to comprehend
the meaning of an instrument, or the effect to be given to the words
of which it is composed. This preliminary knowledge is as indispen-
sable as that of the language in which the instrument is written. A
reference to the actual condition of things at the time, as they ap-
peared to the parties themselves, is often necessary to prevent the
court, in construing their language, from falling into mistakes and
even absurdities."19

In re Smith's Will ${ }^{20}$ presented the question whether a New York will made in 1911 was revoked by a Florida will made in 1924. The New York will dealt only with New York property and expressly provided that "Every provision of this will is to be satisfied out of the property located at my death in said State of New York". The testatrix also stated in this will that it was her intention to make a separate will disposing of her Florida property in which she would direct the payment of her debts. Under the New York will her New York property was not to be used to pay her debts. She also provided in her New York will, "It is my will that no other or later testamentary instrument executed by me shall be deemed to affect in any way the terms and provisions of this instrument unless it is so specified in said other or later instrument."

In 1912 the testatrix executed a Florida will evidently in fulfillment of the purpose expressed by her in the 1911 New York will. She also made a second will in Florida in 1924, using a printed form, which contained this clause: "hereby revoking all former wills by me made". Some of the litigants asserted that the New York will was revoked, others that it was not. The trial court, after admitting parol evidence, concluded that the language of the revocation clause of the 1924 Florida will did not refer to the New York will. The important

20 (1930) 254 N. Y. 283 , 172 N. E. 499 ; (1930) 19 CaLIF. L. Rev. 97. 
extrinsic facts shown by the parol evidence were as follows: At the time of her death the testatrix had property of the value of about $\$ 50,000$. She had securities worth about $\$ 23,000$ which had been in the custody of a New York trust company since 1909. These were the securities which she disposed of by her New York will. When she executed the New York will her nearest relatives were May $P$ and Anna P, daughters of a deceased sister, and Cora $\mathrm{R}$, daughter of another deceased sister. She also had a connection by marriage, Mabel $B$, whom she called her niece. By the New York will the testatrix bequeathed the income from a fund of $\$ 5000$ to May $\mathrm{P}$ and the principal to Mabel B; the income of another fund of $\$ 5000$ to Anna $P$ and the principal sum to Cora $R$. The rest of the property she left to specified charities. By her first Florida will, made in 1912, the testatrix left certain real property to certain persons and the rest of her property, other than her New York securities, to Cora R. After this will the testatrix sold her Florida real estate. In her second Florida will, made in 1924 , she left $\$ 900$ to specified charities; a $\$ 1000$ government bond to a cousin, Amelia $B$, and a $\$ 1000$ government bond to Cora $\mathrm{R}$. At this time May $\mathrm{P}$ was dead and Anna $\mathrm{P}$ was living, but insane. This will contained no residuary clause. From an estate of $\$ 50,000$, gifts to the extent of $\$ 2900$ were made.

Affirming the ruling below, the New York Court of Appeals held that parol evidence was admissible and, in the light of the extrinsic facts, that the words in the 1924 Florida will revoking "all former wills" should not be given a literal meaning, that they neant all former wills except her will disposing of her New York property. Judge Kellogg, J. said,

"It is the modern rule that, "with the exception of direct statements of intention, no extrinsic fact relevant to any legitimate question arising in the interpretation of writings and admissible under the general rules of evidence' can be shut out. Thayer's Preliminary Treatise on Evidence, 445; Wigmore on Evidence, vol. 5, \$2470; Matter of Neil's Estate, 238 N. Y. 138, 144 N. E. 481; Dobbins v. Pratt Chuck Co., 242 N. Y. 106, 151 N.E. 146. Sometimes the rule has been stated with the proviso that extrinsic facts may be shown in cases only 'where the language alone is of doubtful import.' Morris v. Sickly, 133 N. Y. $456,459,31$ N.E. 332,333 . We take this to mean merely that the probable intention of the writer, as indicated by extrinsic facts, may not prevail over the plain meaning of the written word, nor have any force whatever, unless the words incorporated in the writing are susceptible of a meaning which expresses the intent thus disclosed. ..."21

21 Ibid. at 289,172 N.E. 500. 
Upon reviewing the facts above mentioned the court concluded,

"It is thus made apparent that the testatrix, throughout a long period, from the date of her earliest to that of her latest will, cherished the thought that her New York properties, and her properties elsewhere situate, were things apart which should be managed independently and be disposed of separately. Such having been her state of mind and persistent thought, it is highly probable that the testatrix, in executing the Florida will of 1924, wherein an omission to mention the New York properties and the New York will is made, had no intention to revoke the testamentary disposition thereof previously provided for. We think that an intent thus himited finds sufficient expression in the revoking clause employed by her. The testatrix revokes 'all former wills by me made' whereby properties other than those situate in New York State were made the subject of disposition."22

A case from California, a jurisdiction in which the courts attempt to distinguish between written instruments which are plain on the face and those which are not plain, will serve to bring out the merits or demerits of another method of attacking the problem. Wachs $v$. Wachs, ${ }^{23}$ a California case, was an action by the plaintiff against his former co-partner for breach of a contract. Plaintiff and defendant for some years had been engaged in the real estate business as copartners under the name of "Wachs Bros.". In 1931 they dissolved the partnership and entered into a written agreement settling their affairs. In one paragraph entitled "Good Will" it was agreed that "good will" of the old firm existed and that Lionel Wachs, the defendant, should compensate Harold Wachs, the plaintiff, for his share of the "good will". The agreement recited that a list, called "Schedule 10 ", of persons with whom Wachs Brothers had been in contact, was attached to the agreement. The agreement then provided that "Lionel Wachs hereby agrees to pay to Harold Wachs out of the commissions earned from any transactions consummated on or before October 1 , 1934 , a sum not to exceed $\$ 2500$ which shall be payable as follows: when any transaction leading to a commission is closed as to any person on said Schedule 10 . . Lionel Wachs agrees to pay $25 \%$ thereof to Harold Wachs within thirty days after the receipt thereof, until the sum of $\$ 2500$ has been paid." Plaintiff's complaint alleged that the persons listed on Schedule 10 "by reason of their ownership of property, or interests in property, or their contacts with owners 
of property, or owners of interest in property, were persons with or through whom future patronage was anticipated." The names of about 200 persons appeared in Schedule 10. With four or five exceptions they were the names of natural persons, not the names of corporations or partnerships. Addresses followed the names of the persons which in numerous instances were addresses of some bank, investment company or chain store corporation. At the trial plaintiff's offer of oral evidence was rejected. In substance the offered evidence was that the persons named on the list were officers of corporations who had acted for their principals in dealing with the old firm of Wachs Brothers; that the firm of "Wachs Bros." had had no business with them as individuals but had had numerous transactions with them as agents for their principals. The trial court evidently concluded that the writing was plain on its face and hence declined to travel outside the four corners of the writing to ascertain its meaning. Upon appeal the Supreme Court reversed the rulings below concluding that the writing was ambiguous on its face. The report of the decision, after stating the facts in detail, states that the litigants were agreed upon the rules of law governing the disposition of the case; that they agreed that the question involved was whether the language employed was so ambiguous as to permit the introduction of parol evidence in aid of interpretation.

The Supreme Court concluded that the language was not plain on its face but, as contended by plaintiff, was ambiguous and that parol evidence to aid in the process of interpretation was admissible. The court said,

"What then is the meaning, or the "color and content", of the word "transaction" as used in the contract before us? Should the phrase in question be interpreted to mean "when any sale, lease or contract leading to a commission is closed as to any person on said Schedule 10 " or should it be interpreted to mean "when any negotiation (doing of any business) leading to a commission is closed as to any person on said Schedule 10." If the first suggested meaning be given to the word "transaction", then perhaps, the language should be restricted to those cases in which sales, leases or contracts leading to commissions were closed as to the persons named on Schedule 10 as principals. If the second suggested meaning be given, then the language is broad enough to include those cases in which the negotiations leading to a commission were closed as to the persons on said schedule 10 either as principals or as representatives of others. It cannot be said froin a reading of the contract whether the word "transaction" was intended to convey the first or second meaning 
above suggested. It is one of those contracts where the words "consistently admit of two interpretations, according to the subject matter in contemplation of the parties" and in which "parol evidence might be admitted to show the circumstances under which the contract was made and the subject matter to which the parties referred". ... ." "24

What test was applied here to determine whether the words to be interpreted were plain or ambiguous? Was some test used, which was not stated, which reveals to the judicial mind which written words are plain on the face and which are ambiguous? Are the answers to be found by reading the document? Does the court really accept the proposition, without saying so, that the meaning of written words cannot be known until parol evidence of the surrounding circumstances is admitted and examined? Is not recognition of the true solution, namely, examination of the surrounding circumstances, indicated by the court when it speaks of the "suggested meaning" of the term "transactions"? Slight ingenuity by counsel will suffice to give almost all words a "suggested meaning" which will create an ambiguity on the face of the writing. No doubt counsel contending for the interpretation his client has given the writing has in mind the extrinsic facts which he seeks to show by parol evidence. With these facts in mind he "suggests" the meaning of the writing. The "suggestion" seems reasonable to the court and then the conclusion is reached that an ambiguity exists. An ambiguity having arisen, the way is open for the reception of parol evidence-evidence of the facts which produced the "suggestion". This solution of the problem, to say the most for it, is artificial and lacking in clear reasoning. The problem is too important to be solved by a specious formula, which is almost certain to produce confusion. A direct, smiple, and realistic solution, which can easily be stated and applied, is available. No round-about methods are worth while in attacking legal problems. "No star wears a veil." The rule announced in the first two cases discussed-the Reed case and the Smith case-is clearly stated and is easy to understand and to apply, while the rule announced in the third case-the Wachs case-is vague, indefinite and uncertain, difficult to understand, and hence impracticable, if not impossible, to apply consistently. Proof that it has sometimes-or often-produced correct results does not justify the existence of the rule. The results

24 Ibid. at 326,79 P. (2d) at 1087. 
are good when the conclusion is reached that an ambiguity existsbad when the opposite determination is made.

It is not easy to see just how the California court determines which words are plain on the face of a writing and which words are ambiguous. $^{25}$

25 Cf. Barnhart Aircraft Inc. v. Preston (1931) 212 Cal. 19, 24, 297 Pac. 20, 22, where the court treats the case as one presenting an interpretation problem but which really presented an integration problem. There the court said, "A study of the contract in question seems to clearly indicate further that respondent was to design and construct a machine capable of performing a definite requirement, but until such machine had been designed, constructed, set up and had demonstrated its ability to turn out 25,000 brick of specified characteristics in a given time, all within one year from the date of the contract, then and not until then were appellants to be called upon to make any payments or to accept the machine." Here the trial judge who had admitted parol evidence was also reversed, as was the trial judge in the Wachs case, supra note 23. It is difficult to determine from reading California decisions how the trial judges can follow the rule laid down for them by the appellate courts. They are told to admit parol evidence to aid them in interpreting a writing if it is ambiguous on its face; to exclude it if the writing is plain on its face, but they are not given inuch guidance how to determine whether a writing is plain or ambiguous. The trial judges in Wachs $v$. Wachs and Barnhart Aircraft Co. v. Preston probably understood the statement of the Califormia rule but did not know a specific test for determining which words are plain and which are not plain. The rulings of the trial judges in each instance failed to receive approval, probably because they were applying a rule which is based upon the fallacy that words have absolute meanings. Also compare Weinstein v. Moers (1929) $207 \mathrm{Cal}$. 534, 537, 279 Pac. 444, 445, where a property settlement agreement, made between husband and wife, after an action for divorce was filed, read, in part, as follows:

"'... that said payment and agreement is hereby accepted by the parties hereto

in full settlement of any property rights now, or which may hereafter accrue in favor of either of the parties hereto out of said narriage relation, with the right to inherit, whether said claim is based upon the community rights now existing or which may hereafter be created.' "

It was held parol evidence of the surrounding circumstances and the conversations of the parties was admissible and, in light of the evidence admitted, that the words "with the right to inherit", meant that the hushand had no right to take any of the deceased wife's property either by will or succession.

See also Bain v. Continental Assurance Co. (1942) 21 A. C. 1, 129 P. (2d) 396, where the court, without discussion of the question of the admissibility of parol evidence, which had been admitted, properly concluded that a provision in a life insurance contract, plain on its face, did not mean what it said. When literally read the policy provided specifically that the insured before the age of sixty could exchange the policy, without medical examination, for any other form of policy issued by the company. It was held, properly, that he could not exchange it for a policy which carried disability benefits, which the company wrote. At the time the policy was issued the insured's application for a policy containing disability benefits had been rejected. Carter, J. dissented. He said, "The words in the policy are plain and unambiguous." Ibid. at 7, 129 P. (2d) at 399 . They are indeed, but that conclusion did not provide the solution of the problem before the court. In Estate of Kruger (1942) 55 A. C.A. 697, 131 P. (2d) 619, the court interpreted a will in which the testator left to his brother "all my personal property" and to his wife "the rest of my belongings". To support its conclusions that the brother 
Assuming the possibility that man, some day, may devise a set of symbols that will invariably express his intentions it is still too much to hope that all men who execute writings, which may come before the courts, will invariably use these perfect words correctly. There seems to be no possibility that some day we will have a lawyer's paradise, described by Thayer, where all words have a precise and fixed meaning and if the writer has been careful, a judge may sit in his chair, inspect the document and answer all questions respecting it without raising his eyes. ${ }^{26}$

For purpose of the law a theory of words with a single meaning employed by nearly perfect people is indeed a fantastic one which excludes the realities of the kind of world in which we live and in which man is likely to live for many moons to come. Rules of law to be sound, to do justice between man and man or man and the state, cannot be founded upon false assumptions respecting the realities of life. Courts deal with human relations and affairs and any rule of law, for example, a rule for the interpretation of men's written documents which is based upon a state of affairs which does not exist, is an unwise rule which sooner or later will be repudiated.

Perhaps a more nearly perfect world would include a book of words-all known words-in which each word has an absolute mean$\mathrm{mg}$, and a race of men who would always select the right words when they write legal documents. There is no such book; no infallible race of men. Without the perfect book of words and with fallible men it is folly to assume that courts can read their documents and conclude whether they are plain on the face or are ambiguous. For the settlement of disputes in courts of law there is no place for a rule based upon a state of affairs which does not exist. The legal profession deals

was left the testator's watch, lodge emblems, etc. and the widow his furniture, automobile, bank accounts, building and loan certificates, etc., the court said that the words of the will were ambiguous. Frank recognition that the meaning of the will should be determined in the light of the surrounding circumstances would have made unnecessary the questionable statement that the will was ambiguous. The trial judge had concluded that it was not ambiguous and had decided that the furniture, automobile, bank accounts, and building and loan certificates went to the brother. This case again demonstrates the difficult position in which trial judges find themselves under the rulings of the appellate courts respecting plain and ambiguous language.

26 Thayer, op. cit. supra note 7, at 428-9. This description was made in connection with Thayer's discussion of an opinion by Chief Justice Holt in Kinpe v. Johnston (1702) Sty. 293, 82 Eng. Rep. 538. Thayer thought that the opinion of the Chief Justice, who said that he declined to "travel into the affairs of the testator", indicated that the learned Chief Justice had retired into a lawyer's paradise and, forsaking earthly things, had ignored realities. 
with practical questions and our solutions to be good must have a realistic approach.

In a past era formalism was glorified. Courts dealt with words as if they were things, not the "skin [s] of living thought". "The history of the law of interpretation," observed Wigmore, "is the history of progress from a stiff and superstitious formalism to a flexible rationalism." 27 In modern times formalism has given way to a realistic approach. While today most courts, in some situations, continue to state that parol evidence is not admissible if the writing is plain on its face, ${ }^{28}$ some have taken the broader view that parol evidence of the surrounding circumstances, at least, is always admissible to aid the court in interpreting a writing. ${ }^{29}$

Nearly all, if not all the courts, including California courts, recognize that parol evidence is admissible to determine whether the parties have employed trade terms in their writings and what these terms mean in the trade. ${ }^{30}$ These decisions in reality run counter to

279 WIGMORE, op. cit. supra note $1, \$ 2461$.

28 The rule announced by a great many courts is that parol evidence is admissible only where the instrument is ambiguous on its face. For citations of numerous cases from many jurisdictions see 20 AM. JUR. $\$ 1143 ; 32$ C.J.S. $\$ 959 ; 2$ JONEs, op. cit. supra note $7, \$ 450$. Williston has suggested that in many instances when courts have denied the admissibility of parol evidence to vary what was said to be the plain meaning of the words of a written contract, they only meant "that in the particular case the evidence offered would not persuade any reasonable man that the writing meant anything other than the normal meaning of its words would indicate and that, therefore, it was useless to hear the evidence." 3 WIILISTON, op. cit. supra note $15, \$ 629$.

29 Reed v. Insurance $\mathrm{Co}_{0}$, sulpra note 18; Eustice Mining $\mathrm{Co}$. v. Beer Sondheimer \& Co., supra note 17 (an interesting opinion by Judge Learned Hand); In re Tidewater Coal Exchange (D. N. Y. 1923) 292 Fed. 225, (1923) 22 MicE. L. REv. 374; Armstrong Paint \& Varnish Works v. Continental Can Co. (1921) 301 Ill. 102, 133 N. E. 711 ; Kohl v. Frederick (1902) 115 Iowa 517, 88 N. W. 1055; Gumbinsky Bros. Co. v. Smalley (1923) 203 App. Div. 661, 197 N. Y. Supp. 530; In re Smith's Will, supra note 20; Fayter v. North (1906) 30 Utah 156, 83 Pac. 742. See Contracts RestateMENT (Am. L. Inst. 1932) \$\$230, 235; Property Restatement (Ain. L. Inst. 1936) §242; 3 WIILISTON, op. cit. supra note $15, \S 614$.

30 Callahan v. Stanley (1881) 57 Cal. 476 (interpreting the ineaning of the word "stubble" in a lease of agricultural land); Higgins v. California Petroleum etc. Co. (1898) 120 Cal. 629, 52 Pac. 1080 (interpreting the meaning of "gross ton" in an asphalt contract) ; Cooney v. Glide (1929) 97 Cal. App. 77, 275 Pac. 257 (interpreting "color" in a painting contract); Miller v. Wiggins (1910) $227 \mathrm{~Pa} .564,76$ Atl. 711; Mitchell v. Henry (1879) $15 \mathrm{Cl}$. D. 181 (holding "white selvage" meant "black selvage"); 9 WIGMIORE, op. cit. supra note $1, \S 2464 ; 3$ WrusstoN, op. cil. supra note 15, \$614. And also, Ermolieff v. R.K.O. Radio Pictures (1942) 19 Cal. (2d) 543, 122 P. (2d) 3. The Ermolieff case was discussed by the writer in (1942) 30 CALIF. L. REv. 679. It was there held that the words "United Kingdom" in a contract made by persons in the moving picture industry included Eire. Application of the rule that parol evidence is not admissfble 
the rule which prohibits the introduction of parol evidence to disturb plain meaning. On the face of the writing the words mean one thing; when, however, the court is informed of the sense in which such words are used in a particular trade they may mean something else. In these decisions it is sometimes said that the rule against disturbing plain meaning does not apply; that parol evidence is adımissible to show the trade meaning although there is no ambiguity on the face of the writing. ${ }^{31}$

The decisions holding that parol evidence is admissible to identify the object described in a writing also demonstrate the unsoundness of the rule against disturbing plain meaning. Nearly all courts, including those which frequently state that parol evidence is not admissible to aid interpretation where the document is plain on its face, hold that parol evidence is admissible to identify the object described in the writing. ${ }^{32}$ The need for resorting to parol evidence to aid in

where the writing is plain on its face obviously would have precluded the litigant from showing that in the moving picture industry the United Kingdom includes Eire. For numerous cases from nearly all jurisdictions see 32 C.J.S. $\$ 962$.

31 In the Ermolieff case, supra note 30, at 550, 122 P. (2d) at 6, Carter, J. aptly said, "Parol evidence is admissible to establish the trade usage, and that is true even though the words are in their ordinary or legal meaning entirely unambiguous, inasmuch as by reason of the usage the words are used by the parties in a different sense."

329 WIGMORE, op. cit. supra note 1, §2465, and cases cited; 2 JoNEs, op. cit. supra note $7, \S 450$, and cases cited; 20 AMr. JOR. $\$ 1153$, and cases cited. In a leading English case, Macdonald v. Longbottoun [1859] I El. \& El. 977, 983, 120 Eng. Rep. 1177, 1179, where the contract provided that the defendant agreed with the plaintiff to purcliase wool, the wool was described as "your wool". The court held that parol evidence was admissible to show that wool plaintiff liad on his own farm and some purchased by hin from other farmers was meant by the term "your wool". Lord Campbell said, "Tlie only question, therefore, is, what was the subject-matter of the contract, described as 'your wool'? I am of opinion that, when there is a contract for the sale of a specific subject-matter, oral evidence may be received, for the purpose of shewing wliat that subject-matter was, of every fact within the knowledge of the parties before and at the time of the contract. Now Stewart, the defendant's agent, had a conversation before the contract with one of the plaintiffs who stated what wool he had on lis own farm, and what he liad bought from other farms. The two together constituted his wool; and, with the knowledge of these facts, the defendant contracts to buy 'your wool'. There cannot be the slightest objection to the admission of evidence of this previous conversation, which neither alters nor adds to the written contract, but merely enables us to ascertain what was the subject-matter referred to therein."

A leading American case is Stoops v. Smith (1868) 100 Mass. 63, 66. In this case Wells, J., said, "But it is equally well settled that, for the purpose of applying the terms of the written contract to the subject matter, and removing or explaining any uncertanty or ambiguity which arises from such application, parol testimony is admissible, and has a legitimate office. For this purpose, all the facts and circumstances of the transaction out of which the contract arose, including the situation and relations of the parties, may be shown. Gerrish v. Towns, 3 Gray, 82. Herring v. Boston Iron Co. 1 
interpretation in these situations, like the trade language cases, often has been so obvious that arguments for its exclusion have been unconvincing. Description of some objects is not very difficult but for

Gray, 134. Sutton v. Bowker, 5 Gray, 416. Gradley v. Washington, Alexandria \& Georgetown Steam Packet Co., 13 Pet. 89. Price v. Mouat, 11 C. B. (N. s.) 508. The subject matter of the contract may be identified by proof of what was before the parties, by sample or otherwise, at the time of the negotiation. Bradford v. Manly, 13 Mass. 139. Hogins v. Plympton, 11 Pick. 97. Clark v. Houghton, 12 Gray 38. Haven v. Brown, 7 Greenl. 421. The terms of the negotiation itself, and statements therein made, may be resorted to for this purpose. Foster v. Woods, 16 Mass. 116. Sargent v. Adams, 3 Gray, 72. Mumford v. Gething, 7 C.B. (N. S.) 305. Chadwick v. Burnley, 12 Weekly Rep. (Q. B.) 1077." The proposition was neatly stated by Cardozo, J., in Marks v. Cowdin (1919) 226 N.Y. 138, 144, 123 N.E. 139, 141, when he said, "Some description there must be. Its adequacy depends upon the degree of certainty attained when the words are applicd to things. From correspondence we infer identity. (Beckwith v. Talbot, 95 U. S. 289, 292)". See also Laclede Construction Co. v. Moss Tie Co. (1904) 185 Mo. 25, 84 S. W. 76.

In Lewis Publishimg Co. v. Henderson (1930) 103 Cal. App. 425, 284 Pac. 713, a claim was filed against the estate of Mrs. W. for the balance due on a contract to purchase a set of books, "California and Califormans", and portraits of the deceased and her husband to be reproduced from portraits in the books and the steel plates from which the portraits were to be reproduced. The deceased was to receive the books, the steel plates and ten prints from the plates. Part of the agreed price, $\$ 1065$, was unpaid at the time of the death of Mrs. W. Upon delivery of the books, etc., her executor refused payment of the alleged balance due. Evidence was admitted showing that the plates were not entirely hand engraved but were partly machme made, that they were of inferior quality. Evidence also was admitted that plaintiff's agent stated that the plates mentioned were to be entirely hand engraved. The trial court found for the defendant. The judgment below was affirmed. Knight, J., said, "Here the evidence shows that there are various kinds and types of steel plates used in the reproduction of portraits, some being costly, such as those entirely hand engraved, while others are of a cheaper and inferior variety, such as those made partly by machine, and it further shows that the agreement between the parties was made with the distinct understanding that steel plates, entirely hand engraved, were to be used. Therefore, since the memorandum of agreement failed so to state, extrinsic evidence was admissible and, in fact, necessary to explain the ambiguity $m$ the memorandum and to show what the parties intended thereby; and the evidence introduced in this behalf, having relation to a matter upon which the written memorandum was silent, and not being inconsistent therewith, cannot be said to contradict or vary the terms thereof. (Sivers v. Sivers (1893) 97 Cal. 518 [32 Pac. 571].)" $103 \mathrm{Cal}$. App. at $428,284 \mathrm{Pac}$. at 714.

See also Wilson v. Samuels (1893) 100 Cal. 514, 35 Pac. 148, 35 Pac. 559 ; Lemm v. Stillwater Land \& Cattle Co. (1933) 217 Cal. 474, 19 P. (2d) 785; Reid v. St. John (1924) 68 Cal. App. 348, 229 Pac. 863; Kolb v. Rusco (1929) 101 Cal. App. 709, 282 Pac. 397. In the Lemm case the argument was made that parol evidence was not admissible because there was no ambiguity. In that case Shenk, J., said, "On these appeals the Stillwater Company contends that the provisions of paragraphs (6) and (9) of the agreement of July 7, 1925, are elear and unambiguous; that no assistance outside of their terms is required to interpret them, and that the court erred in admitting over objection evidence of the surrounding circumstances and of the negotiations of the parties upon which to base its findings that the items involved in the actions herein were not embraced within nor settled and discharged by the agreement. In other words, 
others the difficulty may be considerable. Fallible men-lawyers and laymen alike-describe objects and also use language to impose obligations upon others and to acquire rights for themselves and there seems to be little difference between the problem of identifying an object described in a writing and the problem of determining what obligation was imposed or what right was acquired. Both problems are often presented in the same instrument. Disputes are often taken into a court, which must decide both questions. The problem in each situation is the meaning of the written words employed. Why is it correct $m$ answering the question as to what obligation was imposed, or what right was acquired, to hold that the proper solution is to determine whether the words are plain on the face of the writing and if they are found to be plain exclude all parol evidence, and likewise correct in answering the question what object was meant by the language employed to declare that an inspection of the writing, only, does not furnish a solution and then conclude that parol evidence

the contention, on that phase of the controversy involving an interpretation of the agreement to support the findings and judgment, is that the effect of admitting evidence of the circumstances surrounding the parties and of the negotiations leading up to the execution of the agreement is to vary the terms of the agreement, which is conceded to be the exclusive memorial of the negotiations of settlement, contrary to the provisions of section 1856, Code of Civil Procedure. The appellant's argument, however, presupposes that the court may not look further than to the language of the paragraphs relied upon by the appellant for an interpretation thereof. The law is to the contrary. A court must look at the contract as a whole and give to each particular clause thereof the modification or limitation or qualification which it is evident from the other parts of the contract the parties intended. (Sec. 1641, Civ. Code; Ogburn v. Travelers Ins. Co., 207 Cal. 50, 53 [276 Pac. 1004]; Stockton Sav. \& L. Soc. v. Purvis, 112 Cal. 236, 238 [44 Pac. 561, 53 Am. St. Rep. 210] ; 6 R. C. L., p. 834 et seq.) In the interpretation of contracts the duty of the court is to ascertain the intent of the parties. Although the language of the contract must govern its interpretation (Civ. Code, secs. 1638, 1939), never theless the meaning is to be obtained from the entire contract and not from any one or more isolated portions thereof. (Hunt v. United Bank \& Trust Co., 210 Cal. 108, 115 [291 Pac. 184]; Kennedy v. Lee, $147 \mathrm{Cal}$. 596, 601 [82 Pac. 257]; Eastman v. Piper, 68 Cal. App. 554 [229 Pac. 1002; 13 C. J., p. 525].) To assist it in the perfornance of this duty the court may look to the circumstances surrounding the parties at the time they contracted (Civ. Code, sec. 1647; Ogburn v. Travelers Ins. Co., supra, at p. 52; Smith v. Carlston, 205 Cal. 541, 550 [271 Pac. 1091]; Henika v. Lange, 55 Cal. App. 336, 339 [203 Pac. 798]), including the object, nature and subject matter of the agreement (6 R. C. L., pp. 836, 837; Eastman v. Piper, supra, at p. 565; Canal Co. v. Hill, 82 U. S. 94, 100, 101 [21 L.Ed.64]), and the preliminary negotiations between the parties ( 6 R.C.I., p. 839), and thus place itself in the same situation in which the parties found themselves at the time of contracting. (Code Civ. Proc., sec. 1860; 6 R. C. L., p. 849; Jersey Island Dredging Co. v. Whitney, 149 Cal. 269, 273 [86 Pac. 509, 691]; Blaeholder v. Guthrie, 17 Cal. App. 297, 300 [119 Pac. 524].)" 217 Cal. at 479, 19 P. (2d) at 788. 
always may be introduced to identify the object described? Each question may present the same problem. When the question is the identification of an object described in a written instrument the necessity for admitting parol evidence is so obvious that no abstract rule excluding it is accepted no matter how plausible the rule seems. This is a situation where the courts have decided that to refuse to look at extrinsic facts may result in failure to settle the dispute of the litigants upon a rational basis and hence produce rank injustice. Here the impact of the facts upon the rule has resulted in the refusal to follow the rule.

Recently the Supreme Court of California in Universal Sales Corp. v. California Press Manufacturing $\mathrm{Co}^{33}$ impliedly, $^{34}$ again $^{35}$ announced the rule that parol evidence is admissible to aid in the interpretation of a written instrument if the imstrument-here a contract-is ambiguous on its face but not admissible if the writing is plain on its face. The rule, impliedly stated, is contrary to specific provisions of the Code of Civil Procedure and to sound principles of law governing the interpretation of writings. Section 1856 of the Code of Civil Procedure is as follows:

"An agreement reduced to writing deemed the whole. When the terms of an agreement have been reduced to writing by the parties, it is to be considered as containing all those terms, and therefore there can be between the parties and their representatives, or succes-

33 (1942) 20 Cal. (2d) 751, 128 P. (2d) 665. Justice Traynor wrote a concurring opinion in which he stated that he did not agree with the premise implied in the majority opinion, written by Curtis, J., in which it was said, impliedly, that parol evidence was properly admitted by the trial court because the contract was aunbiguous on its face, Justice Edmonds concurred in Justice Traynor's opinion.

A majority of the court concluded that the contract was ambiguous on its face and therefore parol evidence was admissible of the surrounding circumstances and the preliminary negotiations to aid the trial judge in determining its meaning.

When the case was first before the court [see (1942) 20 Cal. (2d) 751,118 P. (2d) 291] the conclusion was that the contract was plain on its face and that error lad been committed in the admission of parol evidence. The changed result on rebearing seemingly is due to the conclusion, reached upon further study of all the provisions of the contract, that it was ambiguous on its face. In the first opinion empbasis is given to the proposition that parol evidence is not admissible when the writing is unambiguous on its face. The opimion on rehcaring omits the emplrasis but retains the distinction originally made.

34Justice Curtis said, "The principal problem presented on this appeal consists of a determination of wliether or not the language of the contract is sufficiently certain and definite to render unnecessary a resort to extraneous evidence respecting the circumstances surrounding the execution of the instrument, the situation of the parties, and their intention in executing it." $20 \mathrm{Cal}$. (2d) at 760, $128 \mathrm{P}$. (2d) at 671.

35 Barnhart Aircraft, Inc. v. Preston, supra note 25; Wachs v. Wachs, supra note 23. 
sors in interest, no evidence of the terms of the agreement other than the contents of the writing, except in the following cases:

"1. Where a mistake or imperfection of the writing is put in issue by the pleadings;

"2. Where the validity of the agreement is the fact in dispute.

"But this section does not exclude other evidence of the circumstances under which the agreement was made or to which it relates, as defined in section eighteen hundred and sixty, or to explain an extrinsic ambiguity, or to establish illegality or fraud. The term agreement includes deeds and wills, as well as contracts between parties."

Section 1860, mentioned in Section 1856, is as follows:

"The circumstances to be considered. For the proper construction of an instrument, the circumstances under which it was made, including the situation of the subject of the instrument, and of the parties to it, may also be shown, so that the judge be placed in the position of those whose language he is to interpret." 36

These sections of the Code of Civil Procedure of Califorma make perfectly clear that no distinction exists between writings which are plain on the face and those which are ambiguous on the face of the writing. Section 1856 provides generally that parol evidence is not admissible to add to or subtract from the terms of a written agreement but provides that parol evidence is admissible when (1) a mistake in the writing is put in issue by the pleadings, (2) when the validity of the agreement is the fact in dispute, and (3) that evidence is admissible ". . of the circumstances under which the agreement was made or to which it relates, as defined in section eighteen hundred and sixty, or to explain an extrinsic ambiguity ...." The clause in Section 1856 Code of Civil Procedure "or to explain an extrinsic ambiguity" to be given any effect must mean that parol evidence is admissible although on the face of the writing the meaning is clear. "Extrinsic ambiguities" are ambiguities which are only revealed when facts are alleged to exist which, if true, alter the ordinary meaning of the words in the writing. "Extrinsic ambiguity" is synon-

36 These provisions enacted in 1872 were taken from a Code of Civil Procedure recommended for New York in 1850 by the Commissioner on Practice and Pleading. See New York Code of Crin Procedure (1850) §\$1689, 1693.

Before the adoption of section 1856 and 1860 California Code of Civil Procedure in 1872 the supreme court had announced the rule that parol evidence is not admissible to aid in the interpretation of a writing which is plain on its face. Lennard v. Vischer (1852) 2 Cal. 37; Ruiz v. Norton (1854) 4 Cal. 355. 
omous with "latent ambiguity" which according to the misinterpreted Bacon maxim could be resolved by parol evidence. This view is well expressed im Pacific Indemnity Co. v. California Electric Works ${ }^{37}$ where the court dealt with a provision in an indemnity agreement which, when literally read, was entirely clear. Warmer, J. pro tem, said,

"It will be noted that the qualifying clause to the rule stated in section 1856 of the Code of Civil Procedure says: '... this section does not exclude other evidence ... to explain an extrinsic ambiguity....' Palpably, other evidence means other than the written contract itself. The question therefore is whether there is any extrinsic ambiguity present in the contract in the case at bar. The language used in the contract would seem to be sufficiently broad to indemnify the Standard Oil Company against its own negligence if there exists no extrinsic ambiguity therein. The statutory use of the words 'extrinsic ambiguity' in section 1856 of the Code of Civil Procedure we understand to have the same meaning as latent ambiguity. A latent ambiguity is an uncertanity which arises, not by the terms of the instrument itself, but is created by some collateral matter not appearing in the instrument. (Harney v. Wirtz, 30 N. D.,292 [152 N. W. 803, 807].)

" 'When the intention of the party is clearly expressed, and a doubt exists, not as to the intention, but as to the object to which the intention applies, it is, in the same language, called a latent ambiguity.' (Breckenridge v. Duncan, 9 Ky. 50 [12 Am. Dec. 359].)"

Section 1860 lays down a broad rule for interpretation of written instruments and specifically states that "... the circumstances under which it was made, including the situation of the subject of the instrument, and of the parties to it, may also be shown, so that the judge be placed in the position of those whose language he is to interpret." No distinction is made in these sections between writings which are plain on the face and those which are not. The distinction is not expressly made; it is not impliedly made. It is not even hinted or suggested. It has been incorporated in the code sections by judicial decisions, probably influenced by California cases before 1872 and by decisions from other jurisdictions, where similar statutes did not exist. The code sections are as plain as a pike staff.

The California cases making the distinction came to Mr. Wig-

37 (1938) 29 Cal. App. (2d) 260, 272, 84 P. (2d) 313, 319. Bacon thus defined a latent ambiguity: "That which seemeth certain and without ambiguity for anything that appeareth upon the deed or instrument, but there is some collateral matter out of the deed that breedeth the ambiguity." BAcoN, loc. cit. supra note 7. 
more's attention and he-unquestionably one of the leading scholars in the field of Evidence whose great treatise has widely influenced the course of the American law of evidence in this century-did not exaggerate when he said that the California court has "radically misunderstood" the code sections, and "only confusion can result in this State".38

The distinction made by the Supreme Court of California between words that are plain and words that are ambiguous on the face of the writing is opposed to specific provisions of the Code of Civil Procedure; is unsound in principle; is based upon an unrealistic conception of the nature of words and of the people who use them; and is opposed to the views of the nost competent scholars and the decisions of some of our ablest American judges. Mr. Wigmore's prophecy, judged by past experience with the rule here and in other jurisdictions, seems to have been a wise forecast of things to come. It is to be hoped that, in the not too distant future, the realistic approach of Justices Edmonds and Traynor expressed in the separate concurring opinion written by Justice Traynor, in Universal Sales Corp. v. California Press Manufacturing $\mathrm{Co}^{39}$ will prevail, or, if their views are not accepted, that appropriate amendments will be made to the Code of Civil Procedure which will expressly state that parol evidence of the extrinsic circumstances is admissible in all cases to aid in interpretation so that the judge may be placed in the position of those whose language he is to interpret. Justice Edmonds and Justice Traynor properly imterpreted Sections 1856 and 1860 of the Code of Civil Procedure. Discernment and clarity of expression is revealed in their conclusion that,

"Words are used in an endless variety of contexts. Their meaning is not subsequently attached to them by the reader but is formulated by the writer and can only be found by interpretation in the light of

389 WigaroRe, op. cit. supra note 1, \$2470, n. 11, "In California the Code language (quoted ante, $\$ 2458$, note 3 ) seems to be radically misunderstood in its present bearing. It provides unqualifiedly that 'the circumstances under which the instrument was made' may be shown, for construing it. But this rule, it is now said, 'can only be involsed to explain an ambiguity which appears upon the face of the document itself:' 1931, Barnhart Aircraft Co. v. Preston, 212 Cal. 19, 297 Pac. 20 (citing prior cases). The 'ambiguity' doctrine, correctly considered, has reference only to an offer of expressions of intention (post, \$2470), and not to circumstances in general, nor to the parties' usage or understanding of the meaning of words. The above himitation on the Code provision involves so radical a misapplication of distinct principles that only confusion can result in this State."

${ }^{39}$ Supra note 33. 
all the circumstances that reveal the sense in which the writer used the words. The exclusion of parol evidence regarding such circumstances merely because the words do not appear ambiguous to the reader can easily lead to the attribution to a written instrument of a meaning that was never intended." 40 